Research Articles

\title{
The Modern Flight
}

\author{
${ }^{1}$ Relly Victoria Petrescu, ${ }^{2}$ Raffaella Aversa, ${ }^{3}$ Bilal Akash, ${ }^{2}$ Antonio Apicella and \\ ${ }^{1}$ Florian Ion Tiberiu Petrescu \\ ${ }^{1}$ ARoTMM-IFToMM, Bucharest Polytechnic University, Bucharest, (CE), Romania \\ ${ }^{2}$ Advanced Material Lab, Department of Architecture and Industrial Design, \\ Second University of Naples, 81031 Aversa (CE), Italy \\ ${ }^{3}$ Dean of School of Graduate Studies and Research, American University of Ras Al Khaimah, UAE
}

Article history

Received: 28-08-2017

Revised: 31-08-2017

Accepted: 18-10-2017

Corresponding Author: Florian Ion Tiberiu Petrescu ARoTMM-IFToMM, Bucharest Polytechnic University, Bucharest, (CE), Romania E-mail: scipub02@gmail.com
Abstract: A modern flight involves both a great flight quality and high safety throughout. You can't speak of a quality of flight today unless it provides increased comfort to all passengers in full safety and relaxation. Regardless of the aircraft design type, a minimum level of comfort is required in the passenger cabin so that they feel safe, comfortable, quiet, plus not having the time to get bored if the flight is longer, but to keep constant the sensation of pleasure. For longer journeys, passengers must have the feeling of a vacation and not of a travel that doesn't over. Today, modern ships struggle to provide passengers with extra comfort, who no longer have to look on the walls or on a possible common screen that diffuses a movie that is known or not interesting for passengers as being a bad movie of a bad cinema. Every passenger must have his own laptop, which he can work on, navigate, communicate, or watch a pleasant, personally chosen film so that time passes easily and quickly and the journey being one as special as possible. Another aspect of a successful journey is to ensure increased safety throughout it. This is not easy to accomplish, especially in modern, complicated times, with all sorts of dangers that can occur during a flight. Nor is the fact that the ship is giant, full of people, workers, supervisors, can not completely eliminate all the dangers of a possible terrorist attack on board or from outside the ship, the dangers of air voids, globular lightning, frost, birds, a completely free route ... A large mass of specialists is constantly working to solve these problems. The propulsion system of the ship and its maintenance in the air, are, in the opinion of the authors of this paper, the two essential factors of ensuring one safer flight. For this reason, the paper will focus on the modern propulsion systems of an aircraft and in the most normal way of keeping it in the air. The safest way to keep an airplane in the air known from the oldest to the present day is the use of a navigable airship. On such a flying device, which automatically keeps everything in the air, without the danger of collapsing, with minimal fuel and energy consumption, with great flight safety and high comfort, it is only the problem of the maximum speed of navigation, which may be limited by the high resistance of the aircraft to advance. When we have a pleasure trip, or one on short or medium distances, navigating with airships is always preferred. What can be done when the journey takes place over very long distances and travelers are rushed to arrive at the destination, with the high speed of the aircraft being a priority? At first glance, in such cases, an airship can no longer be used. And yet a modifiable one could be used successfully and in such situations. This is an essential point to be discussed during this work.

Keywords: Modern Flight, Flight Quality, High Safety, Some Special Aircraf, Helicopters, Aerospace, Spacecraft Propulsion, US Army, Jet Engines, Airships 


\section{Introduction}

The modern era of aviation began with the first airplane easier than the air, on Nov. 21, 1783, of a hot air balloon designed by the Montgolfier brothers (Petrescu and Petrescu, 2013a-c, 2012a-b, 2011; Petrescu, 2009). They had limited practical use because they could only travel in the wind. Immediately it felt the need to build a commanded balloon, that is, a dirigible. Jean-Pierre Blanchard flew with the first humanized airship in 1784 and crossed the English Channel in 1785. Perhaps it was not by chance that this happened, but just for that, we might think today that the safest way to keep a flight ship to air is nevertheless the airship. Rigid aircraft has become the first aircraft in the history of mankind capable of transporting passengers and goods over long distances. The most popular aircraft of this type were manufactured by the German company Zeppelin.

The most successful Zeppelin was Graf Zeppelin. It flew over a million miles, including a flight across the world in August 1929 (LZ 127 Graf Zeppelin, From Wikipedia), Fig. 1.

\section{Methods and Materials}

LZ 127 the Zeppelin Grade (D-LZ 127) was a rigid aircraft, built only in Germany, for the purpose of carrying passengers powered by hydrogen as it was at that time, which operated commercially between 19281937. When he entered the commercial service in 1928, he became the first passenger transatlantic passenger service in the world. The name of the aircraft came from the German pioneer of aircraft, Ferdinand von Zeppelin, German nobleman. During its operating period, the airship made 590 flights covering more than 1.7 million kilometers (over 1 million miles) of flight, extremely much for an air pioneer who was still created with not very special materials and its filling being made with hydrogen, a highly flammable gas. The ship was designed to be operated by a crew of 36 officers (men). The LZ 127 was the longest rigid aircraft at the time of its completion, being exceeded only by the USS Akron in 1931. It was dismantled for combat aircraft parts in 1940 , in the Second World War (The Graf Zeppelin).

Zeppelin made his first flight on September 18, 1928, under the command of Hugo Eckener. The ship took off at 3:32 and flew just over three hours before returning to its base in Friedrichshafen, Fig. 2.

A series of successful flights followed, including a 34 and a half hour endurance flight, during which the new German ship was presented to the residents of Ulm, Flensburg, Hamburg, Berlin, Leipzig and Dresden.

Zeppelin's chart made its first commercial passenger trip over the Atlantic, leaving Friedrichshafen at 7:54 on October 11, 1928 and landed at Lakehurst, New Jersey on October 15, 1928, after a flight of 111 hours and 44 minutes. The ship has transported 40 crew members under Hugo Eckener's command and 20 passengers, including US naval officer Charles E. Rosendahl and Hearst newspaper reporter Lady Grace Drummond-Hay.

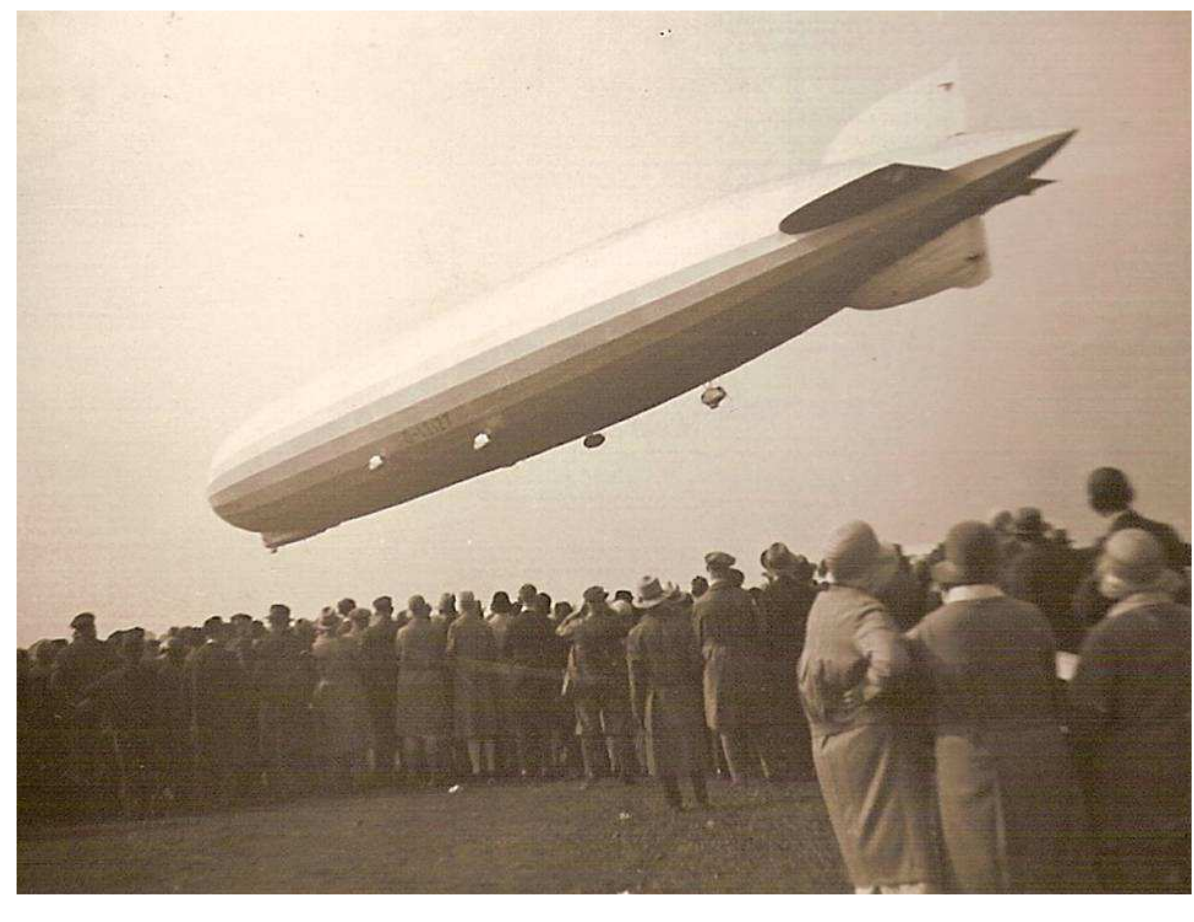

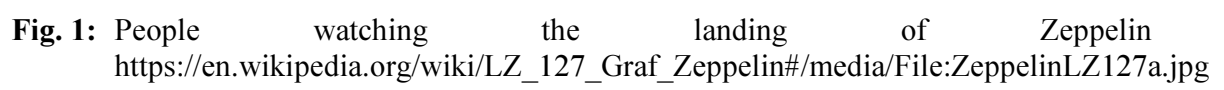
LZ 127. Source: 


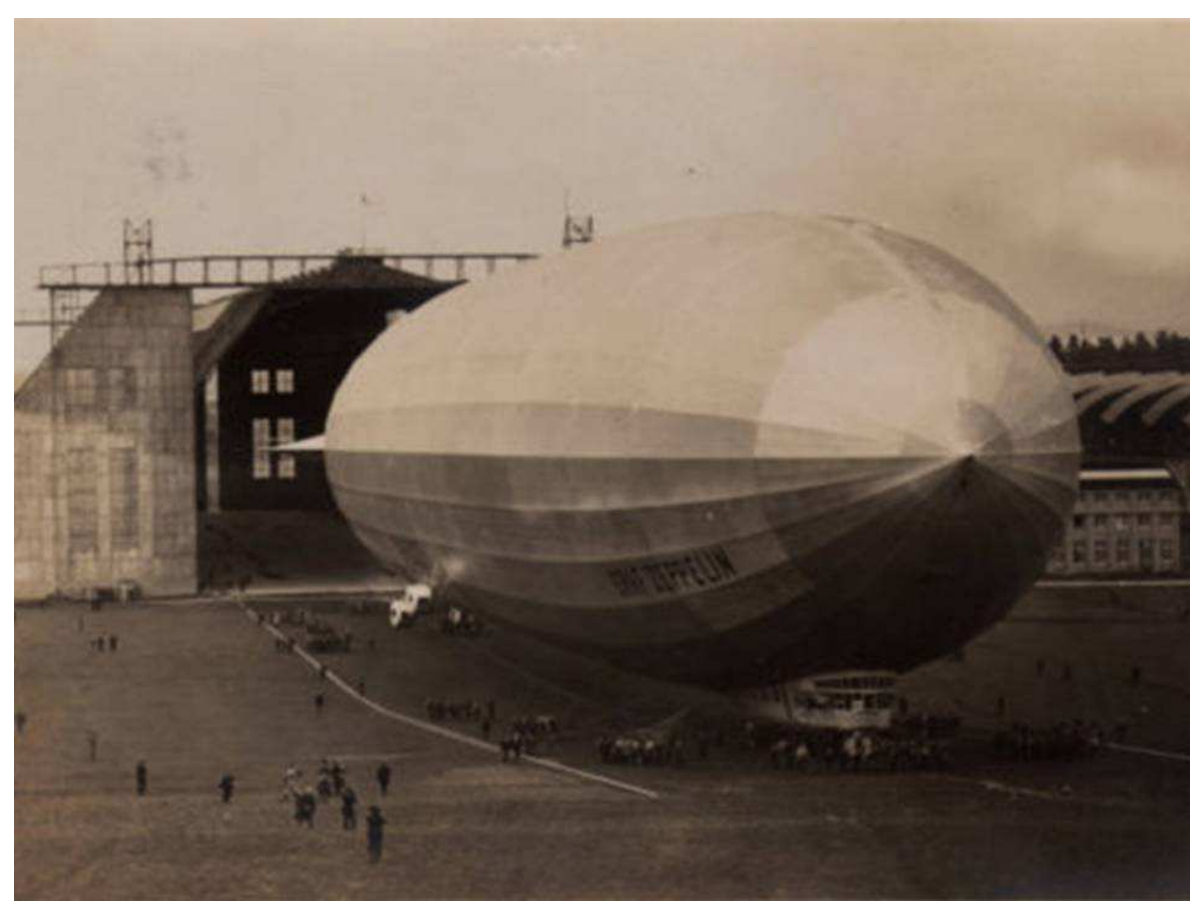

Fig. 2: Graf Zeppelin being led from its hangar for its first flight on September 18, 1928. Source: http://www.airships.net/lz127-grafzeppelin/history/

The first transatlantic crossing of the ship was to end in disaster due to a strong storm on the morning of October 13th. Captain Eckener had entered unusual in the storm at maximum power and speed of the aircraft (it was known that the speed had to be reduced in adverse weather conditions) and the ship had risen in altitude violently because of the unexpected storm and the inexperienced crew member in charge of steering the altitude of the ship (the R-38 and USS Shenandoah airships have broken under similar circumstances), but the commander managed to control the ship and recover it on time, rapidly and very much reducing its travel speed.

Eckener and his officers were able to re-establish control of the ship as soon as their speed had fallen, but they soon found out that the lower wing coverage was broken by the wind, threatening additional damage that would make the ship uncontrollable. Eckener immediately sent a four-man repair team (including his son, Knut Eckener, senior elevator man and future zeppelin commander Albert Sammt and Ludwig Knorr, who will become chief executive on the LZ-129 Hindenburg) to repair the cover even in flight. At the same time, Eckener made the difficult decision to send a distress call, knowing he was in jeopardy for his ship's reputation. The distress signal was soon taken over by the press and newspapers around the world had the opportunity to tell sensational facts about the prolonged destruction of Graf Zeppelin, which happened during his trip over the Atlantic.
Emergency repairs were successful, but the ship encountered a second event, a new storm just ahead of Bermuda. The Zeppelin managed to cross the second storm even though it had a temporarily repaired wing, which has again deteriorated on the occasion of the second storm and managed to reach the US coast on the morning of October 15. After a roundabout from Washington, Baltimore, Philadelphia and New York, to show Zeppelin Graf to the American public, Eckener brought the ship damaged by a safe landing at the United States naval base at Lakehurst, New Jersey on the evening of the 15 th October 1928. The Zeppelin chart was delayed, damaged (Fig. 3) and had just finished the food and water supplies, but Eckener, his crew and passengers were greeted as heroes with a band parade across Broadway in New York City. Always materials used to build aircraft have been a priority (Aversa et al., 2017a-e; 2016a-o; Mirsayar et al., 2017). But at that time, there were no possibilities of today in creating of materials.

The first crossing of the Atlantic in a crewed flight, using a navigable, demonstrated that such a ship can keep on flying even under extremely difficult conditions. Apart from the fact that the ship entered the first storm at very high speed, totally unprepared and poorly coordinated, a major problem was the used material that has been broken in front of a very strong wind (extremely high winds). 


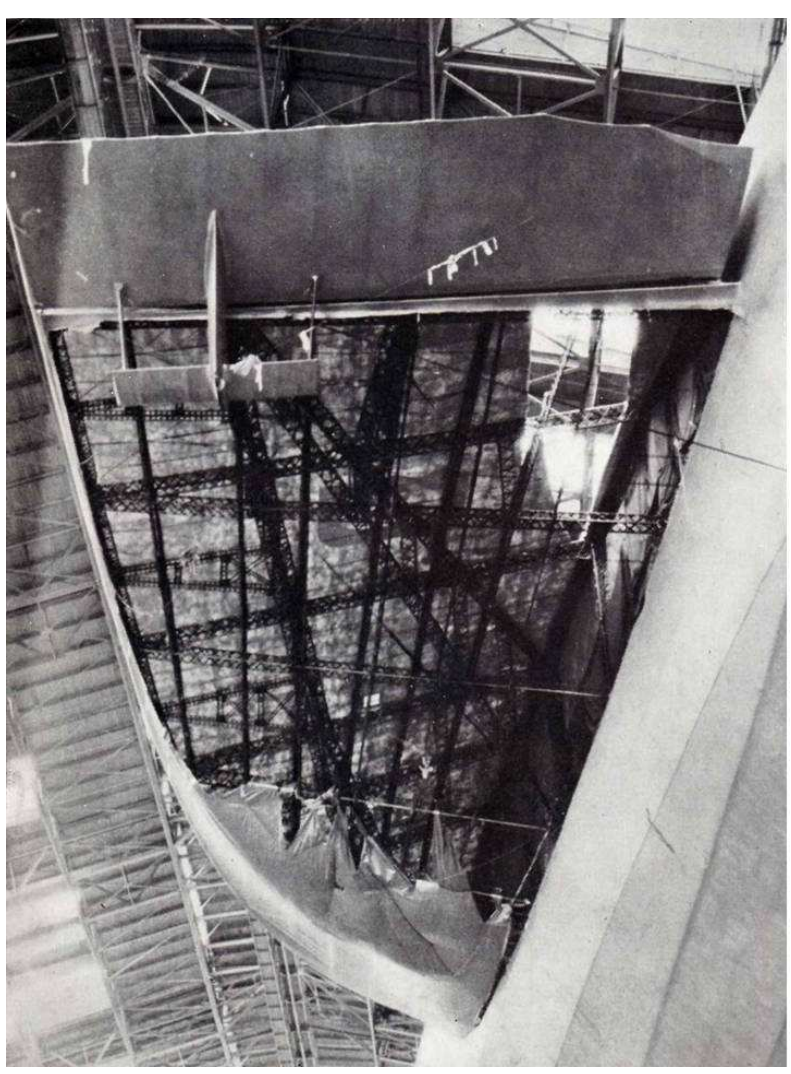

Fig. 3: The damaged port fin after arrival at Lakehurst (view from the floor of the hangar). Source: http://www.airships.net/lz127-graf-zeppelin/history/

\section{Results}

A modern airship, the Airlander, made from special materials can face a hurricane without great difficulty (Fig. 4).

If a modern ship hits an unexpected hurricane, the modern materials that cover it have a very high pressure and impact resistance.

However, today any more dangerous storm is signaled early and can be bypassed or avoided by lifting the ship above the storm.

Speed does not need to be diminished anymore, but instead, the velocity may be increased to avoid the storm or even to take the ship out of the storm area.

A modern airship-like a dirigible ship can easily rise to very high altitudes, or it could even leave the earth's atmosphere without big fuel or energy loss, no pollution, no dangers.

Even more, she might as well return to the earth's atmosphere.

The US Navy has experimented with many original uses of airships. The most original of these was to use these aircraft as aircraft carriers. This is a consequence of the crisis of the 1930s. With the recession, budgets allocated to airships in the US armed forces are reduced.

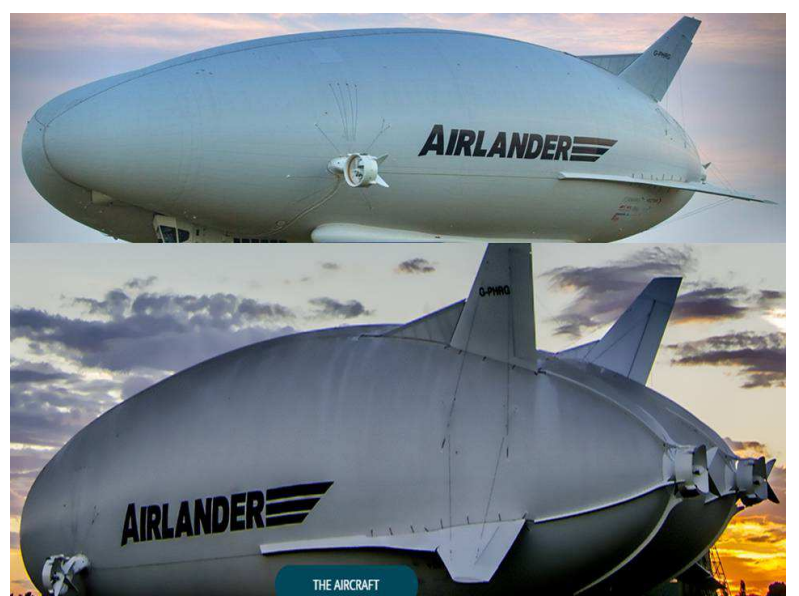

Fig. 4: Airlander-a modern airship. Source: https://www.hybridairvehicles.com/

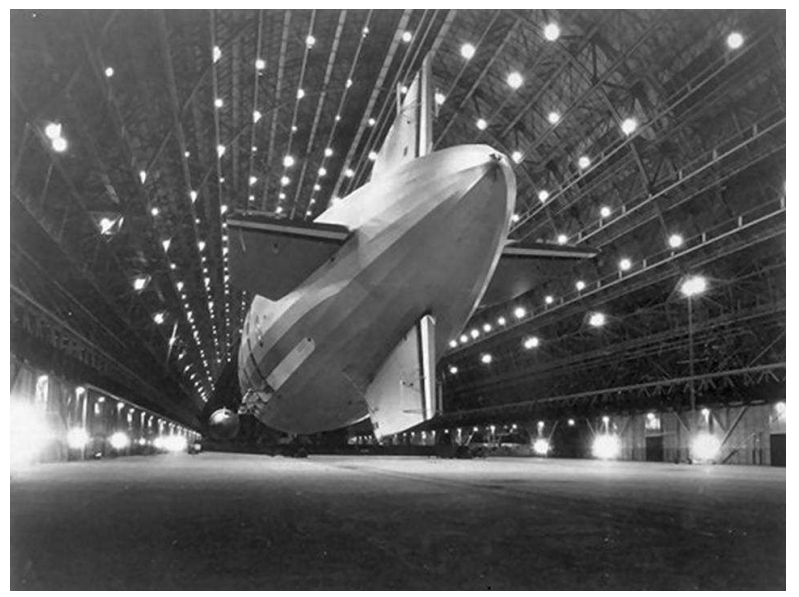

Fig. 5: The USS Macon in its hangar. Source: https://en.wikipedia.org/wiki/USS_Macon_(ZRS-5)

It is ultimately up to the US Navy to develop the employment doctrine as well as the technology of these vessels. Aware of the vulnerability of these devices, the US Navy sailors quickly abandoned the idea of using them for offensive purposes, preferring to assign them to reconnaissance missions. It is within this framework of employment that the various possibilities of carrying airplanes in airships and the technologies and methods to be developed to design and operate such assemblies, will be explored. Two of the three airships were destroyed in accidents only two years after their commissioning (Fig. 5).

Before the Second World War, competition between the airplane and the airship as an instrument of war and reconnaissance was still strong. Autonomy is an asset for the lighter than the air, but its maneuvering capabilities and its protections are limited, which makes it very vulnerable in combat situations. However, following the Treaty of Versailles in 1918, the Allies, intrigued by the success of the German military raids over Great Britain, appropriated 
the technology of the Zeppelin brand and in the United States was created the brand Goodyear-Zeppelin.

Very quickly, it is envisaged to equip the airships as aircraft carriers to assign them to reconnaissance missions, rather than to make them military apparatuses usable in combat. The losses of the German crews of the Zeppelins during the Great War had definitely limited the offensive interest of the dirigibles.

For example, in 1931, as soon as the ZR-4 Akron (which bears the name of the city where it was built) was to be built, was it planned to equip the Navy airships so that they could carry single-seater aircraft that they could dump and recover in flight. The same thing was planned for his "sistership" Macon (launched it two years later in 1933).

Initially, the primary purpose was to carry light aircraft used to increase the air reconnaissance capability of the airship. In the second phase, the biplanes on board were equipped with weapons systems, which could be used to ensure the safety of their mothership, in flight.

Resolutely new, these airships were responsible for developing a doctrine of employment. The cohabitation of a crew of pilots and balloonists was not without difficulty as to the elaboration of this doctrine, the airships post World War I being traditionally envisaged for missions of recognition and very little concerned with the offensive activities or freight. The pilot officers, emphasizing the intrinsic vulnerability of the airship, considered that the airship had to stay behind and use the aircraft taken for reconnaissance missions or even more offensive missions. The officers and crew of the Akron considered that the airship had to carry out the reconnaissance missions to which it had traditionally been assigned and to use the airplanes to ensure its air protection. The premature disappearance of the two airships Akron and Macon did not resolve this debate and put an end to the concept of aircraft airship before a doctrine could be elaborated.

But let's not forget that the materials used at that time did not have the special properties of today and the flight technique used then was very rudimentary.

The US Navy's two aircraft airships are original aircraft from the Navy's previous USS Los Angeles (ZR3 ) research. They were built with an internal duralumin structure and three interior pins. The lift of the dirigible was obtained with 12 gas cells of gelatin and latex, filled with helium. Inside the structure, the ship carried eight 560 horsepower twelve-cylinder engines, designed by the German firm Maybach. These engines were dieselpowered. They were driven by external propulsion propellers. Propellers with propellers could be steered upwards or horizontally to control the airship during the take-off and landing phases.

Their only peculiarity was that it was planned from the outset to equip them with the capacity of carriage of single-seater airplanes releasable and in flight. To this end, a hangar was installed inside the dirigibles, in which the aircraft entered through a T-shaped opening made under the envelope. A release and retrieval device was also provided during catapults and stops for maritime aircraft carriers.

The launching and recovery of the aircraft from the airship is carried out with the help of a hook and anchor system, resting on a trapeze. The crews called these pieces of equipment the flying trapezes. The aircraft usually a biplane - was equipped on its upper wing with a bar for hooking.

For the release, the trapeze hook was engaged on the aircraft support in the airship's hangar. Then the plane was descended by the trapezium and placed in the wake of the dirigible, at a sufficient distance from the envelope. The engine was then switched on and the aircraft could then clear itself from the wake.

For recovery, the biplane had to fly under its airship at a slightly higher speed than the latter. The pilot had to maneuver his apparatus to catch the bar implanted on the upper wing of his apparatus by the hook. He used an approach lateral maneuver to use the tolerance offered by the width of the fastening bar (the device having no margin for maneuver on the vertical axis, more dangerous more enter the aircraft in a collision with the bottom of the envelope of the airship). As soon as the contact between the hook and the bar was obtained, the locking was automatic and the motor had to be cut. The airplane was then lifted by the trapeze and returned to the airship's hangar.

The maneuver was particularly dangerous in wind gusts and even in optimal conditions it was not uncommon for several attempts to be made before the recovery of the aircraft was completed.

Several projects were designed to make Zeppelin airships capable of releasing and fetching fighter jets. There are also many examples of aircraft carriers or lighter aircraft than air in literature and fiction.

The operational airships carrying aircraft are:

- The USS Los Angeles (ZR-3): used as a prototype to test concepts deployed on Akron and Macon. In service from 27 August 1924, removed from service on 24 October 1939

- The USS Akron (ZRS-4): first flight on September 23, 1931, destroyed, with its crew, on April 4, 1933

- The USS Macon (ZRS-5): put into service on June 23, 1933, accident on February 26, 1935

The abandonment of this aeronautical sector after 1935, designed by the US Navy to carry out long-range reconnaissance missions, created a lack in this area until the advent of the radar. Although equipped with radar stations on the Hawaiian Islands, the Admiralty was unable to exploit this new technology5 to identify the Japanese air attack on the morning of 7 December 1941. 
Airships are kind of aircraft. Airships stay in the sky by floating. This is different from aeroplanes that stay in the sky by moving. An airship floats like a balloon. But an airship is different from a balloon. An airship has an engine for power and a way to control its direction of movement. A balloon does not have an engine or a way to control its direction of movement.

Some people may use the word "airship" to mean any kind of aircraft. This is not exactly correct. Technical people use the word "airship" only to mean a aircraft that floats and has both an engine and a way to control its direction of movement (Airship, From Wikipedia).

There are three kinds of airships. The difference is the amount of structure in the airship:

- $\quad$ Rigid airships - Rigid airships have big structures in them. The biggest airships were rigid airships made in the 1920s and 1930s. Big rigid airships were also called dirigibles

- $\quad$ Semi-rigid airships - Semi-rigid airships have small structures in them. There are only a few semi-rigid airships

- Non-rigid airships - Non-rigid airships have no structures in them. Non-rigid airships are also called blimps. Most airships are non-rigid airships. Blimps were used by the United States in WWII to fight against submarines. Blimps are now used mostly for advertising

A balloon satellite (also occasionally referred to as a "Satel loon", which is a trademarked name owned by Gilmore Schjeldahl's G.T. Schjeldahl Company) is a satellite that is inflated with gas after it has been put into orbit (Balloon satellite, From Wikipedia).

Pageos (Fig. 6) was specially launched for the "global network of satellite geodesy", which occupied about 20 full-time observing teams all over the world until 1973.

All together they recorded 3000 usable photographic plates from 46 tracking stations with calibrated allelectronic BC-4 cameras (1:3 / focal length 30 and 45 $\mathrm{cm}(12$ and $18 \mathrm{in}))$. From these images, they were able to calculate the stations' position three-dimensionally with a precision of about 4 meters $(13 \mathrm{ft})$. The coordinator of this project was Professor H. H. Schmid, from the ETH Zurich.

Three stations of the global network were situated in Europe: Catania in Sicily, Hohenpeißenberg in Bavaria and Tromsø in northern Norway. For the completion of the navigational network, exact distance measurements were needed; these were taken on four continents and across Europe with a precision of 0.5 millimeters $(0.020$ in) per kilometer.

The global network enabled the calculation of a "geodetic date" (the geocentric position of the measurement system) on different continents, within a few meters. By the early 1970 s, reliable values for nearly 100 coefficients of the Earth's gravity field could be calculated.

An espionage balloon is a balloon used for spying (Espionage balloon, From Wikipedia).

During the Cold War, espionage balloons launched by the "Free world" had a secondary psychological warfare capability, carrying propaganda pamphlets and consumer goods (which were supposedly not freely available inside Communist states) that would be released or otherwise delivered onto enemy territories.

The advent of spy satellites, coupled with the end of the Cold War, have rendered espionage balloons obsolete.

Surveillance balloon programs include:

- Project Moby Dick

- Project Genetrix

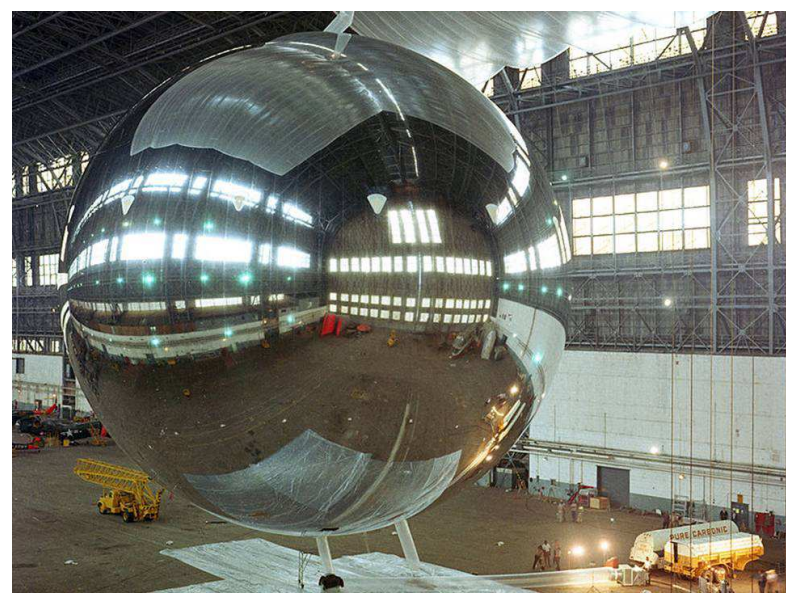

Fig. 6: Test inflation of PAGEOS. Source: https://en.wikipedia.org/wiki/Balloon_satellite\#/media/ File:PAGEOS_Satellite_-_GPN-2000-001896.jpg

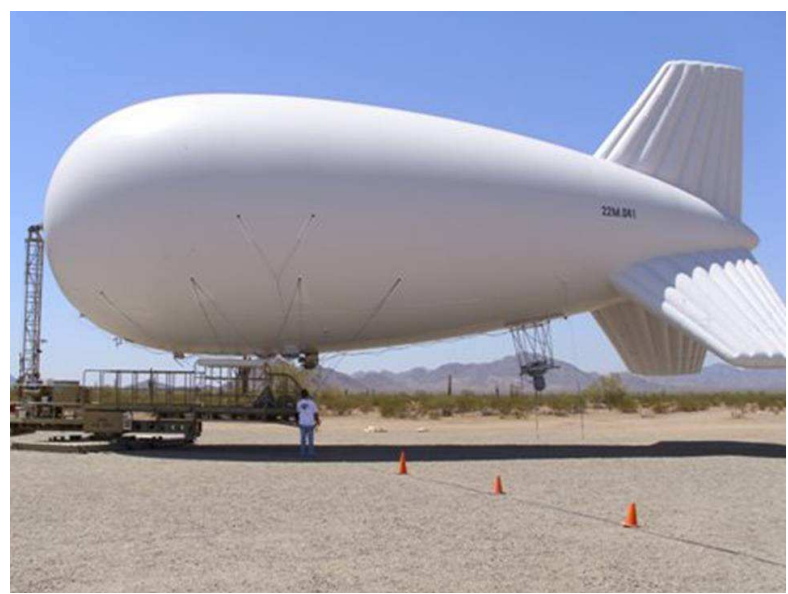

Fig. 7: The predecessor to the Ground Based Operational Surveillance System. Source: https://en.wikipedia.org/wiki/Surveillance_blimp\#/medi a/File:Rapid_Aerostat_Initial_Deployment_System.jpg 


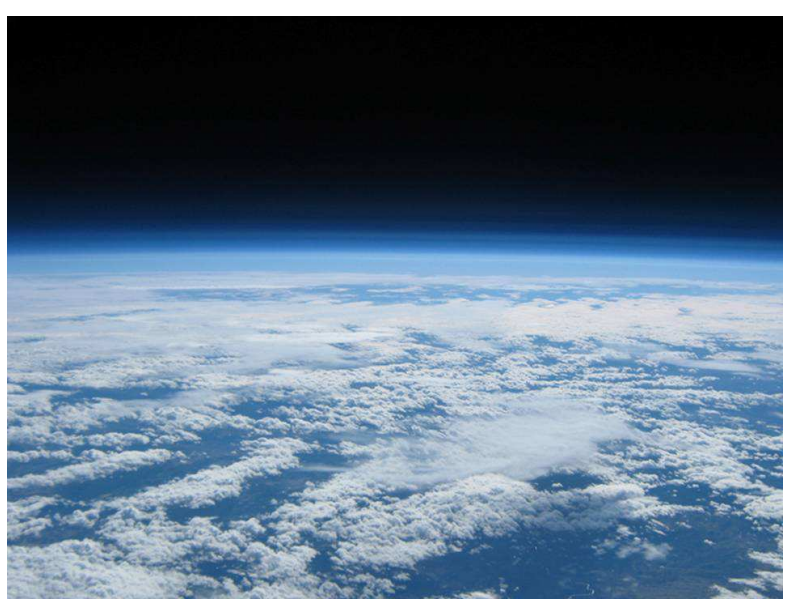

Fig. 8: Photographed at approximately $100,000 \mathrm{ft}(30,000 \mathrm{~m})$ above Oregon using a $1,500 \mathrm{~g}(3.3 \mathrm{lb})$ weather balloon. Source: altitude_balloon

A surveillance blimp (Fig. 7) is a type of airborne early warning and control aircraft, typically as the active part of a system which includes a mooring platform, communications and information processing. Example systems include the U.S. JLENS and Israeli Aeronautics Defense Skystar 300 (Surveillance blimp, From Wikipedia).

High-altitude balloons are unmanned balloons, usually filled with helium or hydrogen and rarely methane, that are released into the stratosphere, generally attaining between 18,000 to 37,000 meters $(59,000$ to $121,000 \mathrm{ft} ; 11$ to $23 \mathrm{mi})$. In 2002, a balloon named BU60-1 attained $53.0 \mathrm{~km}(32.9 \mathrm{mi} ; 173,900 \mathrm{ft})$.

The most common type of high-altitude balloons are weather balloons (High-altitude balloon, From Wikipedia). Other purposes include use as a platform for experiments in the upper atmosphere. Modern balloons generally contain electronic equipment such as radio transmitters, cameras, or satellite navigation systems, such as GPS receivers.

These balloons are launched into what is termed "near space", the area of Earth's atmosphere where there is very little air, but where the remaining amount generates too much drag for satellites to remain in orbit.

Due to the low cost of GPS and communications equipment, high-altitude ballooning is a popular hobby, with organizations such as UKHAS assisting the development of payloads (Fig. 8).

Manned high-altitude balloons were used from the 1930 s to 1960 s for research and in seeking flight altitude records.

\section{Discussion}

$\mathrm{P}-791$ is an aerodynamic/aerodynamic experiment developed by Lockheed-Martin Fig. 9.

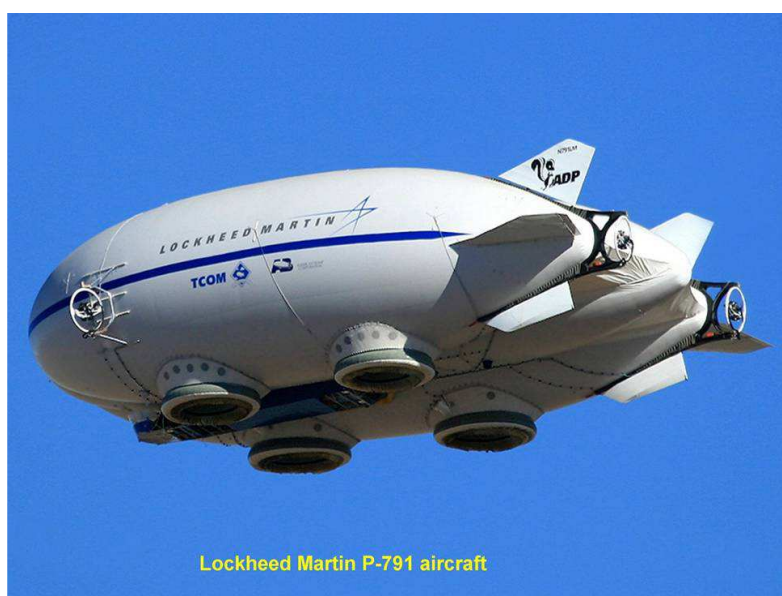

Fig. 9: Lockheed martin P-791 aircraft. Source: Petrescu and Petrescu (2013c)

The first flight of P-791 was on January 31, 2006, aboard the aircraft test company, aboard Palmdale 42. It has a unique shape in three boxes with disk buffers at the bottom for landing. A very similar project can be seen in the vehicle of the Multilingual Vehicle (LEMV).

P-791 is an example of a hybrid aircraft. In such drawings, a part of the weight of the craft and its useful load are supported by aerostatic lifting (floating) and the rest is supported by an aerodynamic lift.

The combination of aerodynamic and aerostatic lifting is an attempt to benefit both from the high speed of aerodynamic craft and the aerostatic lifting capacity. Critics of the hybrid approach have considered it "the worst of both worlds" in that such craft requires a landing and landing track, is difficult to control and protect on the ground and has relatively low aerodynamic performance.

Proponents of hybrid projects argue that these deficiencies can be overcome by advanced technologies. In particular, it has been proposed that the buoyancy control mechanisms reduce or eliminate the need for a runway.

The world's largest airplane, Airlander 10, a combination of airplane, airship, helicopter and airplane, made its first flight Wednesday after months of training and years of research and funding in 2016 (Fig. 10).

The flight did not take long - just $20 \mathrm{~min}$, landing being a problem, in Cardington, north of London, CNN shows.

His design gave him the nickname " Flying Ass, " but the aircraft is ready to show the world what it is capable of.

The way he shows it gave him the name of "Flying Fund". But the biggest flying machine is ready to prove what it is, at the end of this month when it leaves the hangar. Airlander 10 has a length of $92 \mathrm{~m}$ and this summer will make six flights to demonstrate its technology. 


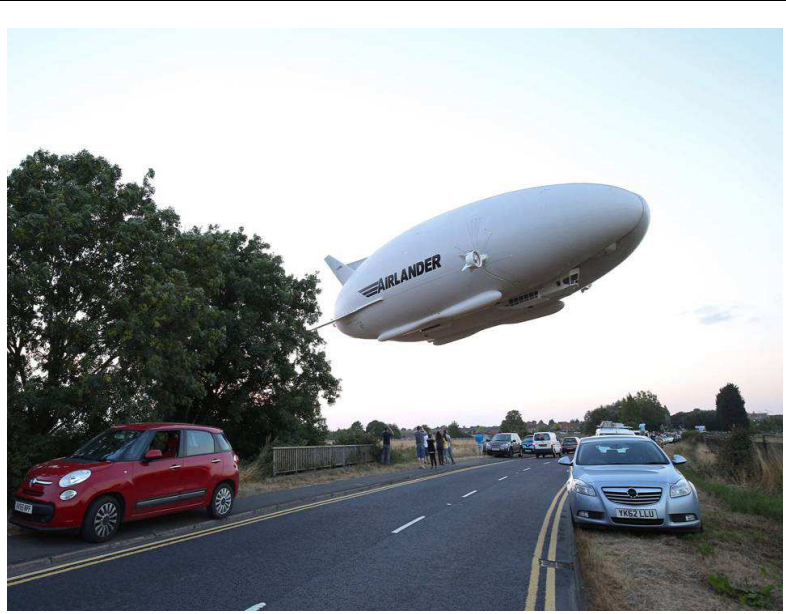

Fig. 10: The ship has a good maneuverability regardless of altitude and can keep on flying at any height Source: Airlander 10 images

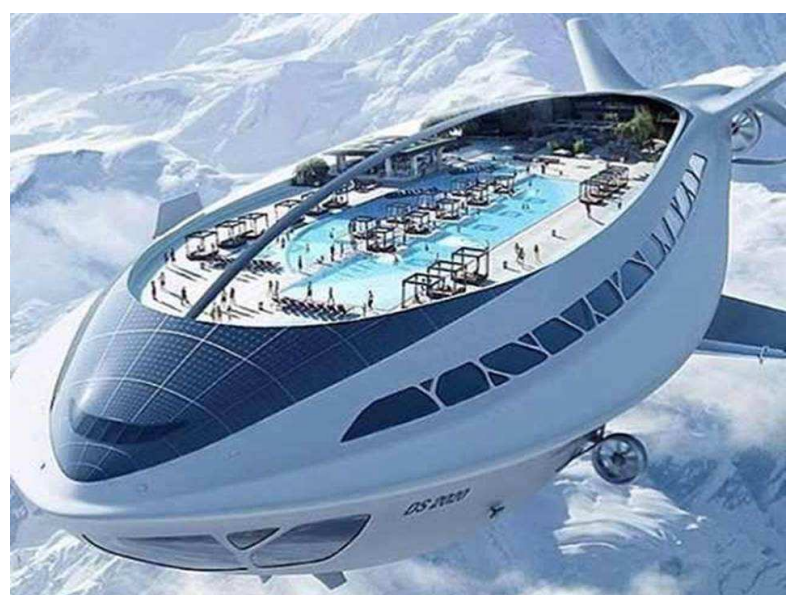

Fig. 11: The passenger's cabin above the ship can be developed to create enhanced comfort conditions, with swimming pools, gardens, bars, sports grounds Source: Airlander 10 images

Hybrid Air Vehicle, the company behind the aircraft, presented details of the routes and maneuvers that will be used to put the hybrid aircraft on its route.

The 92-meter-long aircraft, 26 tall and $43.5 \mathrm{~m}$ wide, was due to fly on Sunday, but the time was postponed due to technical problems.

Airlander 10 is a combination of a plane and a dirigible, being $15 \mathrm{~m}$ longer than the largest passenger aircraft in the world. It will fly at an altitude of $1,219 \mathrm{~m}$ at a speed of $74 \mathrm{~km} / \mathrm{h}$.

The aircraft will fly over the Cardington area in the UK. Another test to which Airlander 10 will be placed will be flying $138 \mathrm{~km}$ at an altitude of $3048 \mathrm{~m}$ at a speed of $111 \mathrm{~km} / \mathrm{h}$.

A modern airship can have elegant shapes and can also be designed for pleasure trips (Fig. 11).
This is a modern, solid, economic ship, capable of climbing easily at any altitude and additionally capable of increasing its speed to very high values for a dirigible.

\section{Conclusion}

In this paper it is proposed to return to modern airships, equipped with modern technologies, with special flying machines, with special resistant materials, loaded with helium, an inert gas.

Their great advantage is that they can keep themselves alone in the air without high energy consumption, or other devices.

\section{Acknowledgement}

We acknowledge and thank Mr Taher M. AbuLebdeh, Associate Prof at North Carolina A and T State Univesity, United States and Mr Muftah H. El-Naas PhD MCIC FICCE QAFCO Chair Professor in Chemical Process Engineering Gas Processing Center College of Engineering Qatar University and Ms Shweta Agarwala, Senior Research Scientist at Singapore Center for 3D Printing Nanyang Technological University Singapore for their suggestions and comments.

\section{Author's Contributions}

All the authors contributed equally to prepare, develop and carry out this manuscript.

\section{Ethics}

This article is original and contains unpublished material. The corresponding author confirms that all of the other authors have read and approved the manuscript and no ethical issues involved.

\section{References}

Airlander. https://www.hybridairvehicles.com/

Airship, From Wikipedia, the free encyclopedia. https://simple.wikipedia.org/wiki/Airship

Aversa, R., D. Parcesepe, R.V. Petrescu, G. Chen and F.I.T. Petrescu et al., 2016b. Glassy amorphous metal injection molded induced morphological defects. Am. J. Applied Sci., 13: 1476-1482.

DOI: 10.3844/ajassp.2016.1476.1482

Aversa, R., D. Parcesepe, R.V.V. Petrescu, F. Berto and G. Chen et al., 2017d. Process ability of bulk metallic glasses. Am. J. Applied Sci., 14: 294-301. DOI: 10.3844/ajassp.2017.294.301

Aversa, R., E.M. Buzea, R.V. Petrescu, A. Apicella and M. Neacsa et al., 2016e. Present a mechatronic system having able to determine the concentration of carotenoids. Am. J. Eng. Applied Sci., 9: 1106-1111. DOI: 10.3844/ajeassp.2016.1106.1111 
Aversa, R., F. Tamburrino, R.V. Petrescu, F.I.T. Petrescu and M. Artur et al., $2016 \mathrm{~d}$. Biomechanically inspired shape memory effect machines driven by muscle like acting NiTi alloys. Am. J. Applied Sci., 13: 1264-1271. DOI: 10.3844 /ajassp.2016.1264.1271

Aversa, R., F.I.T. Petrescu, R.V. Petrescu and A. Apicella, 2016a. Biomimetic FEA bone modeling for customized hybrid biological prostheses development. Am. J. Applied Sci., 13: 1060-1067. DOI: 10.3844/ajassp.2016.1060.1067

Aversa, R., F.I.T. Petrescu, R.V. Petrescu and A. Apicella, 2016o. Flexible stem trabecular prostheses. Am. J. Eng. Applied Sci., 9: 1213-1221. DOI: 10.3844/ajeassp.2016.1213.1221

Aversa, R., R.V. Petrescu, A. Apicella and F.I.T. Petrescu, 2016i. Mitochondria are naturally micro robots-a review. Am. J. Eng. Applied Sci., 9: 991-1002. DOI: 10.3844/ajeassp.2016.991.1002

Aversa, R., R.V. Petrescu, A. Apicella and F.I.T. Petrescu, 2016j. We are addicted to vitamins $C$ and E-A review. Am. J. Eng. Applied Sci., 9: 10031018. DOI: 10.3844 /ajeassp.2016.1003.1018

Aversa, R., R.V. Petrescu, A. Apicella and F.I.T. Petrescu, 2016k. Physiologic human fluids and swelling behavior of hydrophilic biocompatible hybrid ceramo-polymeric materials. Am. J. Eng. Applied Sci., 9: 962-972. DOI: 10.3844 /ajeassp.2016.962.972

Aversa, R., R.V. Petrescu, A. Apicella and F.I.T. Petrescu, 20161. One can slow down the aging through antioxidants. Am. J. Eng. Applied Sci., 9: 1112-1126. DOI: 10.3844/ajeassp.2016.1112.1126

Aversa, R., R.V. Petrescu, A. Apicella and F.I.T. Petrescu, 2016m. About homeopathy or «Similia similibus curentur $\gg$. Am. J. Eng. Applied Sci., 9: 1164-1172. DOI: 10.3844/ajeassp.2016.1164.1172

Aversa, R., R.V. Petrescu, A. Apicella and F.I.T. Petrescu, 2016n. The basic elements of life's. Am. J. Eng. Applied Sci., 9: 1189-1197. DOI: 10.3844/ajeassp.2016.1189.1197

Aversa, R., R.V. Petrescu, A. Apicella, I.T.F. Petrescu and J.K. Calautit et al., 2017c. Something about the $\mathrm{V}$ engines design. Am. J. Applied Sci., 14: 34-52. DOI: 10.3844/ajassp.2017.34.52

Aversa, R., R.V. Petrescu, B. Akash, R.B. Bucinell and J.M. Corchado et al., 2017b. Kinematics and forces to a new model forging manipulator. Am. J. Applied Sci., 14: 60-80. DOI: 10.3844/ajassp.2017.60.80

Aversa, R., R.V. Petrescu, F.I.T. Petrescu and A. Apicella, 2016c. Smart-factory: Optimization and process control of composite centrifuged pipes. Am. J. Applied Sci., 13: 1330-1341.

DOI: 10.3844 /ajassp.2016.1330.1341
Aversa, R., R.V. Petrescu, F.I.T. Petrescu and A. Apicella, 2016h. Biomimetic and evolutionary design driven innovation in sustainable products development. Am. J. Eng. Applied Sci., 9: 1027-1036. DOI: 10.3844/ajeassp.2016.1027.1036

Aversa, R., R.V. Petrescu, R. Sorrentino, F.I.T. Petrescu and A. Apicella, 2016f. Hybrid ceramo-polymeric nanocomposite for biomimetic scaffolds design and preparation. Am. J. Eng. Applied Sci., 9: 1096-1105. DOI: 10.3844/ajeassp.2016.1096.1105

Aversa, R., R.V.V. Petrescu, A. Apicella and F.I.T. Petrescu, 2017a. Nano-diamond hybrid materials for structural biomedical application. Am. J. Biochem. Biotechnol., 13: 34-41.

DOI: 10.3844/ajbbsp.2017.34.41

Aversa, R., R.V.V. Petrescu, B. Akash, R.B. Bucinell and J.M. Corchado et al., 2017e. Something about the balancing of thermal motors. Am. J. Eng. Applied Sci., 10: 200.217. DOI: 10.3844/ajeassp.2017.200.217

Aversa, R., V. Perrotta, R.V. Petrescu, C. Misiano and F.I.T. Petrescu et al., 2016g. From structural colors to super-hydrophobicity and achromatic transparent protective coatings: Ion plating plasma assisted $\mathrm{TiO} 2$ and $\mathrm{SiO} 2$ Nano-film deposition. Am. J. Eng. Applied Sci., 9: 1037-1045.

DOI: 10.3844/ajeassp.2016.1037.1045

Balloon satellite, From Wikipedia, the free encyclopedia. https://en.wikipedia.org/wiki/Balloon_satellite

Espionage balloon, From Wikipedia, the free encyclopedia.

https://en.wikipedia.org/wiki/Espionage balloon

High-altitude balloon, From Wikipedia, the free encyclopedia.

https://en.wikipedia.org/wiki/High-altitude_balloon

LZ 127 Graf Zeppelin, From Wikipedia, the free encyclopedia.

https://en.wikipedia.org/wiki/LZ_127_Graf_Zeppelin.

Mirsayar, M.M., V.A. Joneidi, R.V.V. Petrescu, F.I.T. Petrescu and F. Berto, 2017. Extended MTSN criterion for fracture analysis of soda lime glass. Eng. Fracture Mechanics, 178: 50-59.

DOI: 10.1016/j.engfracmech.2017.04.018

Petrescu, F.I. and R.V. Petrescu, 2011. Memories About Flight. 1st Edn., CreateSpace, pp: 652.

Petrescu, F.I. and R.V. Petrescu, 2012b. New Aircraft II. 1st Edn., Books on Demand, pp: 138.

Petrescu, F.I.T., 2009. New aircraft. Proceedings of the 3rd International Conference on Computational Mechanics, Oct. 29-30, Brasov, Romania.

Petrescu, R.V. and F.I. Petrescu, 2013a. Lockheed Martin. 1st Edn., CreateSpace, pp: 114.

Petrescu, R.V. and F.I. Petrescu, 2013b. Northrop. 1st Edn., CreateSpace, pp: 96. 
Petrescu, R.V. and F.I. Petrescu, 2013c. The Aviation History or New Aircraft I Color. 1st Edn., CreateSpace, pp: 292.

Petrescu, R.V. and FIT. Petrescu, 2012a. Northrop. Books on Demand, ISBN-13: 978-3848209323, pp: 142.
Surveillance blimp, From Wikipedia, the free encyclopedia.

https://en.wikipedia.org/wiki/Surveillance_blimp

The Graf Zeppelin.

Airships.net. http://www.airships.net/lz127-graf-zeppelin/history/ 